\title{
First Report of Anthracnose Disease of Peace Lily [Spathiphylllum wallisii Regel.] Caused by Colletotrichum gloeosporioides from West Bengal, India
}

\author{
Katakam Mounika*, Birendranath Panja and Jayanta Saha \\ Department of Plant Pathology, Faculty of Agriculture, B.C.K.V., \\ Mohanpur-741252, Nadia, West Bengal, India \\ *Corresponding author
}

\begin{tabular}{|l|}
\hline K e y w o r d s \\
Anthracnose, \\
$\begin{array}{l}\text { Spathiphyllum, } \\
\text { Peace lily, } \\
\text { Ornamental } \\
\text { diseases, Foliage } \\
\text { disease. }\end{array}$ \\
\hline Article Info \\
\hline $\begin{array}{l}\text { Accepted: } \\
\text { 14 September } 2017 \\
\text { Available Online: } \\
\text { 10 October } 2017\end{array}$ \\
\hline
\end{tabular}

\section{Keywords}

Anthracnose, Spathiphyllum, Peace lily, diseases, Foliage disease.

\section{Accepted:}

Available Online:

October 2017

\section{A B S T R A C T}

Peace lilies or Spath [Spathiphylllum wallisii Regel.] grown in the garden of AgriHorticultural Society of India at Alipore road, Kolkata, West Bengal are found to be attacked severely by anthracnose disease. The characteristic symptoms appeared on the underside of the leaves near the leaf margins where necrotic lesions were observed with brown wavy margins and ash coloured centres over which light brown to black, superficial, erumpent acervuli, 271.6 - $467.9 \times 198.6$ - 312.5 $\mu$ sized with setae measuring $97.6-138.8 \times 7.6-13.9 \mu, 1-2$ septate, black with pointed tips were observed. Conidia were single celled, hyaline, cylindrical with both ends rounded, eguttulate, $14.4-23.1 \mathrm{x}$ $2.3-4.6 \mu$ in dimension. On the peptone agar medium (PAM) which had been proven ideal medium for acervuli production and sporulation, the pathogen produced hyaline hyphae, covered $90 \mathrm{~mm}$. diameter of Petri plate within 9 days after inoculation with huge production of acervuli and conidia. Hyphae were hyaline, thin, septate and $2.3-7.9 \mu$ wide. On the PAM medium, acervuli were $498.8-879.4 \mu$ in diameter; setae were numerous, dark black, 1-2 septate, unbranched with pointed tips and $202.1-380.3 \times 10.9$ $-18.8 \mu$ in size. Conidia were hyaline, single celled, eguttulate, cylindrical to rod shaped with both ends rounded, $18.4-28.3 \times 4.0-6.3 \mu$ in size. Pathogenicity test of the isolated fungus had been established under laboratory condition following detached leaf technique. There was no detailed record of work done on anthracnose disease of Spathiphyllum wallisii. The causal anthracnose fungus had been identified as Colletotrichum gloeosporioides, from West Bengal by comparing with morphological descriptions of the Colletotrichum spp. described by Suttons (1980) and Colletotrichum gloeosporioides descriptions given by Saccardo (1884). It was the first record of this pathogen on this host from India as well as from West Bengal.

\section{Introduction}

Spathiphyllum, commonly known as Spath or Peace lilies is an economically important ornamental plant, grown throughout the world including India and West Bengal. It is a genus of about 40 species of monocotyledonous flowering plants in the family Araceae, native to tropical regions of the Americas and southeastern Asia (Table 1).
It is a striking indoor plant with elegant dark green leaves that are often more than a foot long and huge fragrant white flowers, called spaches, on an off-white stalk or stem called a spadix. The peace lily has strong symbolic significance and a good market value. It thrives in the shade in temperatures below $55^{\circ} \mathrm{F}$ and removes harmful toxins like 
acetone, ammonia, benzene, ethyl acetate, formaldehyde, methyl alcohol, trichloroethylene and xylene. Thus is rated as a top performer in NASA's clean air study. It has been reported from different parts of the world including India that Spathiphyllum is approximately attacked by 5 fungal and few bacterial and viral diseases which reduce the economic value of the plant and make them less marketable by reducing their aesthetic value. Anthracnose disease severely infects the foliage and rapidly destroys the whole plant.

Literature suggests that the genus Spathiphyllum suffers from anthracnose caused by Colletotrichum sp. but there are no records of work done on it.

The root and petiole rot of potted Spathiphyllum plants caused by Cylindrocladium spathiphylli was first reported from Italy by Carrai et al., (1990). Subsequently, the disease was reported from Hawaii and Florida, USA (Uchida et al., 1992), China (Jiang et al., 1997), Taiwan (Chen et al., 1998) Africa (Schoch et al., 1999), Japan (Horiuchi et al., 2000) and from Distrito Federal of Brazil (Reis et al., 2004). The occurrence of grey mould disease on Spathiphyllum sp. was noted during 1989-94 from Tokyo Metropolis, Japan (Takeuchi et al., 1995). The root and crown rot of Spathiphyllum wallisii caused by Phytophthora parasitica was reported for the first time in the State of Sao Paulo, Brazil by Fischer et al., (2004) and from Taiwan (Ann, 2000). Alternaria leaf spot of Spathiphyllum was reported from Argentina by Cheheid et al., (2000)

The bacterial leaf rot disease of peace lily caused by Pectobacterium carotovorum sub sp. carotovorum was observed in Argentina (Alippi et al., 2009). The first report of TSWV and INSV in ornamental and vegetable plants in Slovenia was done by Mavric and Ravnikar, 2001. Mertelik et al., (2002) first reported impatiens necrotic spot virus on Spathiphyllum sp. from Italy.

From the literature it is evident that no work had been carried out on Spathiphyllum diseases in India drawing the research focus on to this topic.

\section{Materials and Methods}

A detailed study on the disease along with its causal agent has been conducted during present investigation. The diseased leaf sample of Spathiphylllum wallisii Regel. Grown inside and outside of the greenhouse of Agri-Horticultural society of India, No.1, Alipore Road, Kolkata, West Bengal (located at $22^{\circ} 53^{\prime} \mathrm{N}$ latitude and $88^{\circ} 33^{\prime} \mathrm{E}$ longitude) were collected in brown paper packets and detailed in situ description of symptoms and necessary field photography of the diseased plant or its parts were taken. The severity of the foliage damage caused was assessed using the 0 - 6 scale (Table 2). The percent damage caused was recorded by visual observation and scoring the plants in the greenhouse.

Samples kept in brown paper packets were brought to the laboratory and examined for the presence of asexual fruit bodies, acervuli. Experimental studies like isolation, purification culture, micro-photography, identification, pathogenicity testing of the isolated pathogens etc. were conducted following standard protocol under laboratory condition of the University, B.C.K.V.

The purification of the isolated pathogen was carried out on PDA (Potato Dextrose Agar) medium but the fungus failed to produce acervuli on the medium. Thus after further studies using different media combinations it was identified that PAM (Peptone agar medium) was the ideal medium for acervuli 
production and sporulation of the isolated pathogen. Series of slides were prepared from culture or infected parts for morpho-metric studies of fungal spores, spore bearing and other structures. Micro-photograph of all fungal structures was taken with help of Compound microscope or Karl Zeis Phase Contrast Microscope (under 10x, 20x, 40x $\& 100 \mathrm{x})$ and by using Canon Powers Shot A640 camera. Dimensions (e.g. length and breadth) of conidia, acervuli and hyphae of fungi were measured using Axio Vision (Rel. 4.8) software. For pathogenicity establishment detached healthy leaves after proper cleaning with sterile distilled water and absolute alcohol, were pin pricked and artificially inoculated with fungal mat while pin pricked uninoculated (only agar bit) leaves were used as control.

These were covered with transparent polythene packets for 48 hours and observed regularly till symptom development. The pathogen was re-isolated from the inoculated diseased parts of leaf and compared with the fungal culture isolated initially from diseased Spathiphyllum wallisii leaf.

\section{Results and Discussion}

At the study location, the disease severity and sporulation of the pathogen basically started from May and continued up to November to end of January. Affected leaf samples were collected from the garden house during $2^{\text {nd }}$ week of January, 2015 and last week of May, 2016. The disease severity was $26-45 \%$ based on $0-6$ scale.

\section{Characteristic symptoms of anthracnose disease on Spathiphyllum wallisii}

Infection began as small oval necrotic lesions with brown margins and ash colored centres. Spots were sometimes surrounded by yellow halo. The prominent symptoms were generally observed on the underside of the leaves near the leaf margins where necrotic lesions were observed with brown wavy margins and ash colored centre. Black fruiting bodies i.e. acervuli appeared as dot like structures which were scattered on the grey portion. Upon binocular observation black structures could be viewed to be present superficially.

\section{Pathogenicity establishment}

Pathogenicity of the pathogen was established by inoculating detached leaf under laboratory condition. The inoculated leaf produced same symptoms as observed in field. Thus the pathogen was re-isolated from the inoculated diseased parts of leaf and compared with the fungal culture isolated initially from diseased leaf.

\section{Cultural characteristics of the fungus observed on various media}

On PDA medium the fungus produced white mycelial growth initially. Later the hyphae turned black. Fluffy mycelial growth covered the media completely without any productions of fruiting bodies. Sometimes black structures were visible on the undersurface of the plate.

On peptone agar medium, hyaline and sparsed mycelial growth was observed. Acervuli were produced in linear manner which were initially hyaline but turned to black finally. The acervuli size increased gradually towards the periphery of the plate.

Morpho-metrical descriptions of various structures of the pathogen obtained from Peace lily and on PAM

On the host, light brown to black, dot like, superficial, erumpent, many acervuli were produced which were 271.6 - 467.9 (av. 376.3) x $198.6-312.5$ (av. 240.4) $\mu$ in size. 


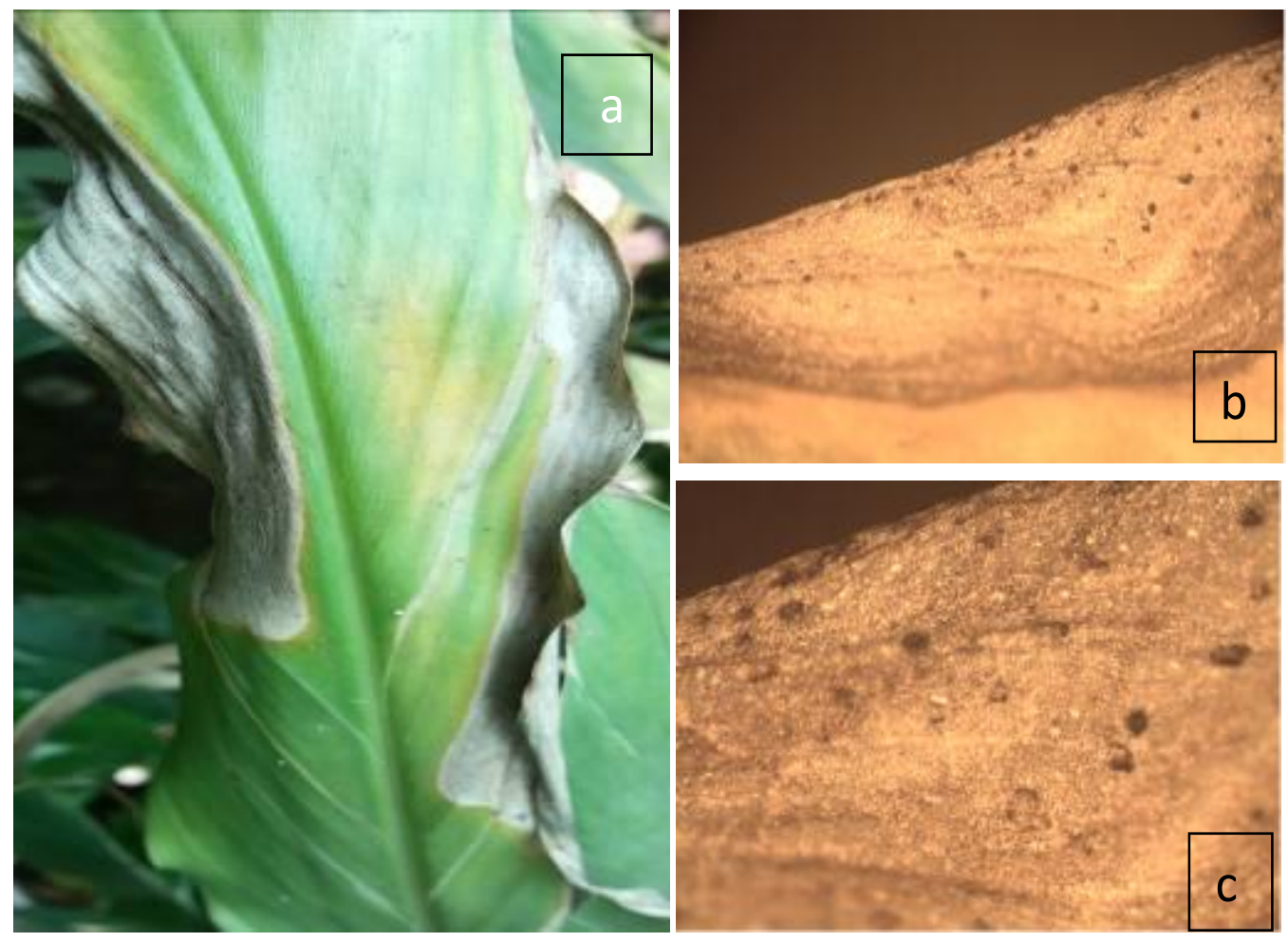

Plate 1 a: Blighting of Spathiphyllum leaf with black dot like acervuli scattered over it (Plate $1 \mathrm{~b}$ and 1c- Binocular view of acervuli)
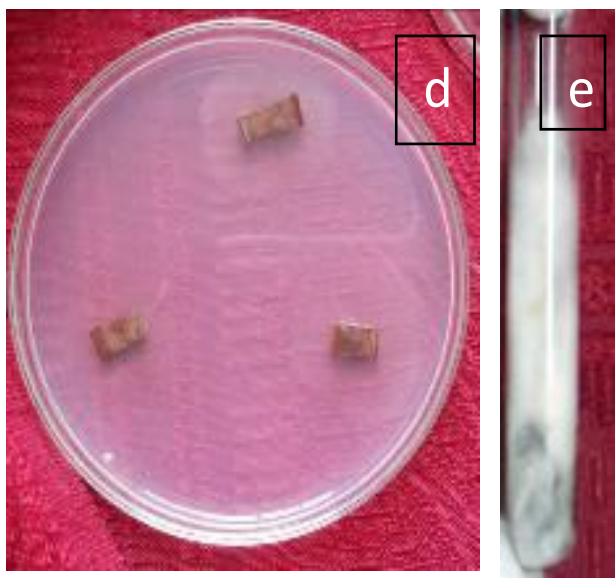

Plate 1d, e: Isolation and purification of Colletotrichum gloeosporioides from infected leaf of Spathiphyllum

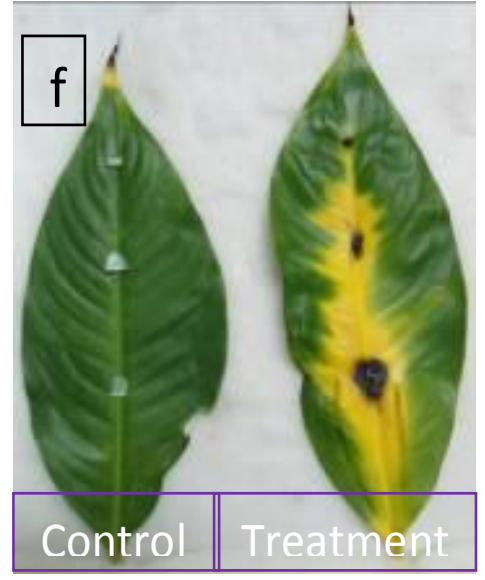

Plate 1f: Pathogenicity establishment of Colletotrichum gloeosporioides on Spathiphyllum leaves under laboratory condition. 


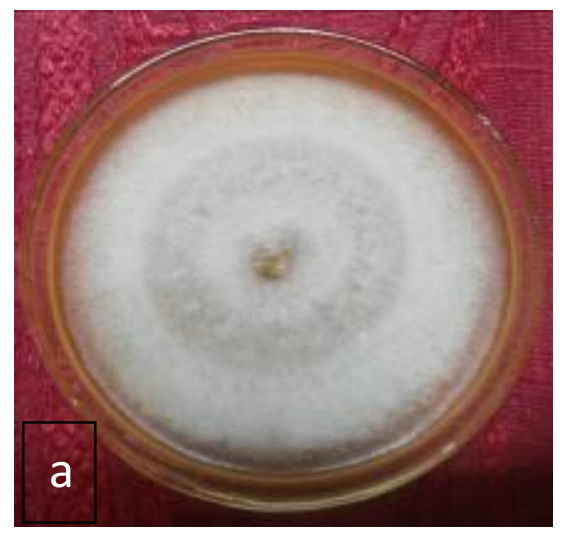

a. PDA medium

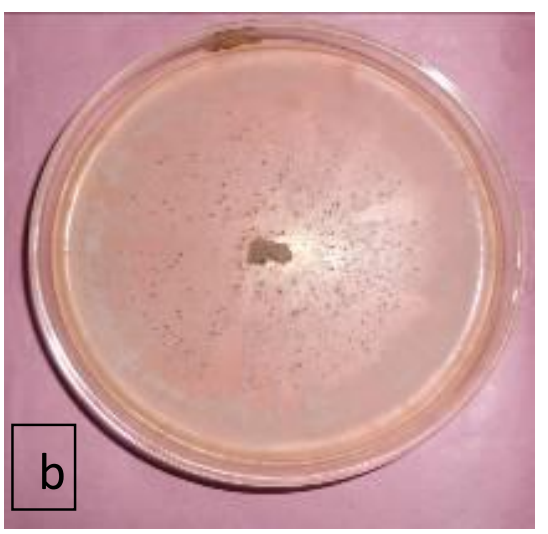

b. Peptone agar medium

Plate 2 a, b: Cultural characteristics of

Colletotrichum gloeosporioides of Spathiphyllum on different media
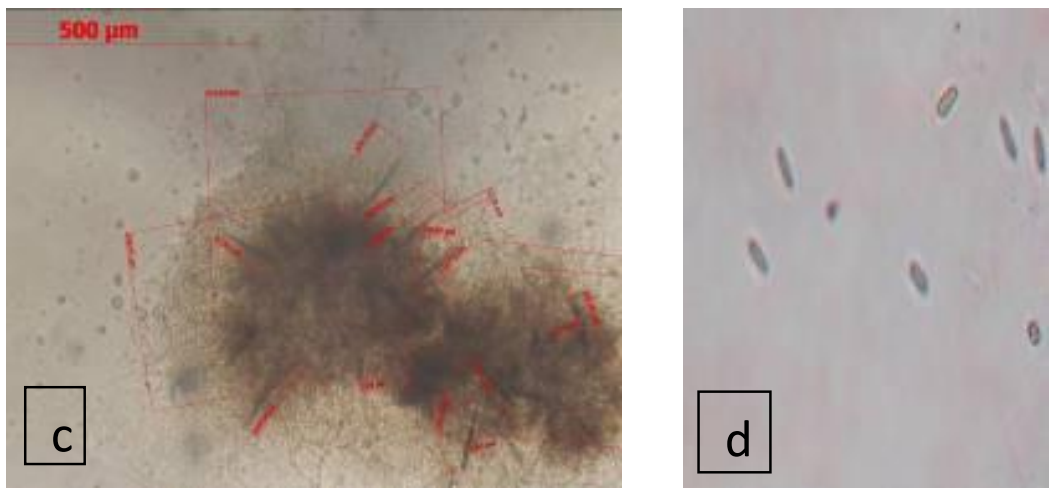

Plate 2 c, d: Microscopic view of avervuli bearing setae and conidia produced on Spathiphyllum
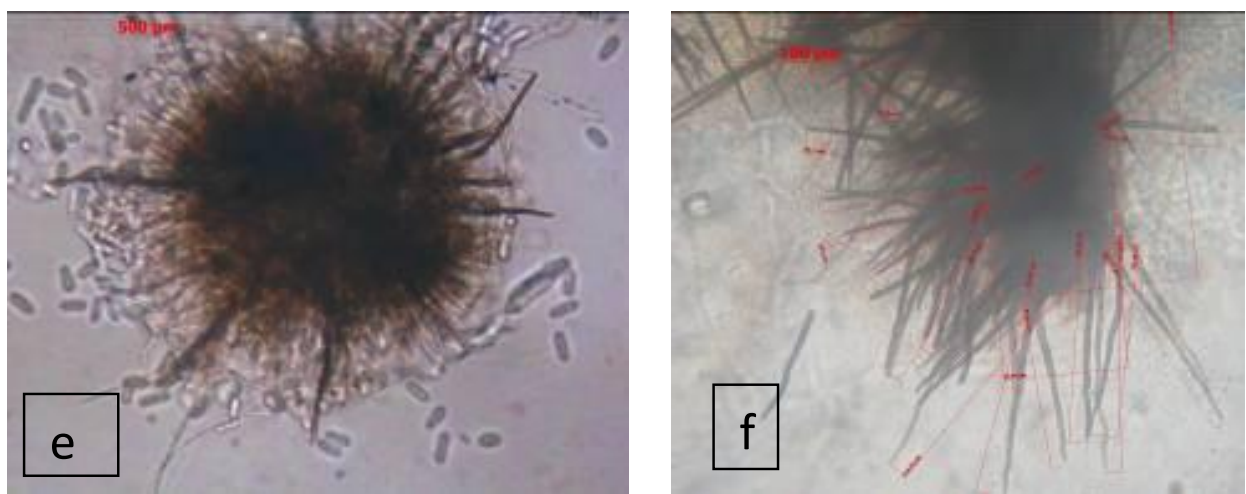

Plate 2 e, f: Microscopic view of avervuli bearing numerous setae and conidia produced on Peptone agar medium 
Table.1 Disease spectrum of Spathiphylllum

\begin{tabular}{|l|l|}
\hline Disease & Causal organism \\
\hline Fungal Diseases & \multicolumn{4}{|l|}{$\mid$} \\
\hline Root and petiole rot & Cylindrocladium spathiphylli \\
\hline Grey mould & Botrytis cinerea \\
\hline Alternaria leaf spot & Alternaria alternate \\
\hline Myrothecium disease & Myrothecium roridum \\
\hline Phytophthora blight & Phytophthora parasitica $[$ Phytophthora nicotianae var. parasitica]. \\
\hline Bacterial leaf rot & Pectobacterium carotovorum sub sp. carotovorum. \\
\hline Viral diseases & $\begin{array}{l}\text { Impatiens necrotic spot virus (INVS) and Tomato spotted wilt } \\
\text { virus(TSWV) }\end{array}$ \\
\hline
\end{tabular}

(Source: CAB Abstracts)

Table.2 Descriptions of $0-6$ disease scoring scale with respective reaction categories

\begin{tabular}{|c|l|l|}
\hline Scale & \multicolumn{1}{|c|}{ Description } & \multicolumn{1}{|c|}{ Reaction categories } \\
\hline 0 & No infection or 0\% infection & Immune \\
\hline 1 & $1-5 \%$ leaf area /length covered by disease & Highly resistant \\
\hline 2 & $6-10 \%$ leaf area /length covered by disease & Resistant \\
\hline 3 & $11-25 \%$ leaf area /length covered by disease & Moderately resistant \\
\hline 4 & $26-50 \%$ leaf area /length covered by disease & Moderately susceptible \\
\hline 5 & $51-75 \%$ leaf area /length covered by disease & Susceptible \\
\hline 6 & $76-100 \%$ leaf area /length covered by disease & Highly susceptible \\
\hline
\end{tabular}

Setae were few to numerous, 1 - 2 septate, black to brown colored, unbranched, 97.6 138.8 (av. 114.3) x $7.6-13.9$ (av. 11.4) $\mu$ in size with pointed tips. Conidia were single celled, hyaline, cylindrical with both ends rounded, eguttulate, $14.4-23.1$ (av. 18.4) $\mathrm{x}$ $2.3-4.6$ (av. 3.7) $\mu$ in dimension.

On the peptone agar medium, acervuli were produced in huge number. Hyphae were hyaline, thin, septate and $2.3-7.9$ (av. 5.1) $\mu$ wide. The acervuli were $498.8-879.4$ (av. 645.2) $\mu$ in diameter, black and dot like and may be grouped together sometimes.

There were huge variations in acervuli sizes. Setae were very numerous, dark black, 1-2 septate, unbranched with pointed tips, 202.1 380.3 (av. 325.4) x 10.9 - 18.8 (av. 14.4) $\mu$ in size. Conidia were hyaline, single celled, eguttulate, cylindrical to rod shaped with both ends rounded, $18.4-28.3$ (av. 22.2) x $4.0-$ 6.3 (av. 4.6) $\mu$ in dimension.

There was no detailed record of work done on anthracnose disease of Spathiphyllum wallisii. After studying and delineating on mycelial, conidial and acervuli characteristics of above mentioned isolated pathogen and comparing it with the descriptions of the Colletotrichum spp. described by Suttons (1980), it was found grossly similar with Colletotrichum gloeosporioides. Then the above mentioned description of our isolated pathogen was also verified with the description of Colletotrichum gloeosporioides given by Saccardo (1884). He described that conidiomata were acervulus, amphigenous, mostly epiphyllous, subepidermal. Setae were often present on acervuli but sometimes arising alone from stomata, forming dense fascicles and bearing enteroblastic conidia 
apically. Conidiogenous cells were discrete, enteroblastic, phialidic, hyaline and smooth. Conidia were slimy, formed singly, cylindrical, (10 -) 15 - 20(- 25) x (3 -) 4 - $6 \mu$ in size, apex obtuse, base sub-acute, aseptate, guttulate, hyaline, smooth, forming septum before germination. Appressoria with entire or sometimes slightly irregularly lobate margin were ovate, globose or ampulliform, brown to medium brown, $8-12 \times 6-9 \mu$ in size.

But the conidia produced by anthracnose pathogen on Spathiphyllum wallisii plant were hyaline, cylindrical with both ends rounded, eguttulate, 14.4 - 23.1 (av. 18.4) x $2.3-4.6$ (av. 3.7) $\mu$ in dimension and on peptone agar medium it was hyaline, single celled, eguttulate, cylindrical to rod shaped with both ends rounded, 18.4 - 28.3 (av. 22.2) x $4.0-$ 6.3 (av. 4.6) $\mu$ in size. So, the present anthracnose pathogen of Spathiphyllum wallisii can be considered as Colletotrichum gloeosporioides. It was the first record of this pathogen on this host from India as well as from West Bengal.

\section{Acknowledgment}

First and foremost I would like to thank the Almighty god for giving me this opportunity. I feel unfathomable euphoria to pronounce my heartful veneration and gratitude to Prof. B.N. Panja, Department of Plant Pathology, BCKV.I further extend my sincere gratitude to Dr. J. Saha and Prof. A. Basu, Department of Plant Pathology and Dr. S. Bhattacharyya, Department of Genetics and Plant breeding for providing their sincere guidance, keen interest, inestimable inspiration and valuable suggestions throughout the course of investigation. I further extend my sincere thanks to In-charge, Agri-Horticultural society of India for helping me in collection and identification of various ornamental plant samples.

\section{References}

Alippi, A. M., and Lopez, A. C. 2009. First report of Pectobacterium carotovorum sub sp. carotovorum on Spathiphyllum wallisii in Argentina. Plant-Disease. 93(8): 842-843.

Ann, P. J., and Tsai, J. N. 2000. Phytophthora blight of peace lily in Taiwan. PlantPathology-Bulletin. 9(4): 145-150.

Carrai, C., and Garibaldi, A. 1990. Cylindrocladium spathiphylli agent of root and petiole rot of Spathiphyllum grown for cut flowers. InformatoreFitopatologico. 40(6): 41-43.

Cheheid, A. L., Wright, E. R., Lopez, S. E. and Codazzi, A. M. R. 2000. First report of Alternaria leaf spot of Spathiphyllum sp. in Argentina. Plant-Disease. 84(3): 370.

Chen, Y. K., Kuo, C. H. and Chen L. C. 1998. Cylindrocladium root and petiole rot of Spathiphyllum spp. new to Taiwan. Annals-of-the-PhytopathologicalSociety-of-Japan. 64(5): 481-484.

Fischer, I. H., Martins, M. C., Lourenco, S. A. and Abreu, F. M. 2004. Occurrence of Phytophthora parasitica in peace lily in Brazil. Fitopatologia-Brasileira. 29(6): 690.

Horiuchi, H., Hagiwara, H., Izutsu, S. and Taguchi, Y. 2000. Occurrence of Cylindrocladium root and petiole rot of Spathiphyllum. Proceedings-of-theKansai-Plant-Protection-Society. 42: $15-22$.

Jiang, Z. D., and Qi P. K. 1997. Inspection of the brown rot of Spathiphyllum pallas. Acta-Phytopathologica-Sinica. 27(1): 71-74.

Mavric, I., and Ravnikar, M. 2001. First report of tomato spotted wilt virus and Impatiens necrotic spot virus in Slovenia. Plant-Disease. 85(12): 1288.

Mertelik, J., Mokra, V., Gotzova, B. and Gabrielova, S. 2002. Occurrence and 
identification of Impatiens necrotic spot tospovirus in the Czech Republic. ActaHorticulturae. 568: 79-83.

Reis, A., Mafia, R. G., Silva, P. P., Lopes, C. A. and Alfenas, A. C. 2004. Cylindrocladium spathiphylli, causal agent of Spathiphyllum root and collar rot in the Federal District - Brazil. Fitopatologia-Brasileira. 29(1): 102.

Saccardo. $1884 . \quad$ Colletotrichum gloeosporioides (Penz.) Penz. \& Sacc., Atti R. Ist. Ven. Sci. Lett. Art., Ser., 2: 6.

Schoch, C. L., and Crous, P. W. 1999. First report of Cylindrocladium root and petiole rot of Spathiphyllum in South
Africa. South-African-Journal-ofBotany. 65(3): 208-211.

Sutton, B.C., 1980. The Coelomycetes, CMI, Kew, Surrey, p.696.

Takeuchi, J., Horie, H. and Hirano, T. 1995. Gray mold of some garden plants in Tokyo is caused by Botrytis cinerea Persoon. Proceedings-of-the-KantoTosan-Plant-Protection-Society. $\quad 42$ : 105-107.

Uchida, J. Y., and Aragaki, M. 1992. Further characterization of Cylindrocladium spathiphylli from Spathiphyllum in Hawaii and Florida. Mycologia. 84(5): 810-814.

\section{How to cite this article:}

Katakam Mounika, Birendranath Panja and Jayanta Saha. 2017. First Report of Anthracnose Disease of Peace Lily [Spathiphylllum wallisii Regel.] Caused by Colletotrichum gloeosporioides from West Bengal. Int.J.Curr.Microbiol.App.Sci. 6(10): 1509-1516. doi: https://doi.org/10.20546/ijcmas.2017.610.180 